\title{
Eimeria minima n. sp. (Apicomplexa: Eimeriidae) from the Japanese quail (Cuturnix cuturnix japonica) in Brazil ${ }^{*}$
}

\author{
Eimeria minima n. sp. (Apicomplexa: Eimeriidae) da codorna (Cuturnix \\ cuturnix japonica) no Brasil
}

Marcel Teixeira, ${ }^{\star \star}$ Carlos Wilson Gomes Lopes***

\begin{abstract}
Oocysts from feces of Japanese quails (Cuturnix cuturnix japonica) were described. Sporulated oocysts were spherical to subspherical and measured $17.31 \pm 1.87$ to $16.45 \pm 1.72 \mu \mathrm{m}$ in size with shape index $1.05 \pm 0.04$. The oocyst wall was thin and smooth, and was consisted of two distinct layer, outside layer was brownish while the inner one was hyaline. Few polar granules were present but without a micropyle or an oocyst residuum. Sporocysts were ovoid with $10.43 \pm 1.11$ to $5.92 \pm 0.58 \mu \mathrm{m}$ in diameter. Sporocyst residuum was present with visible granules with tactful Stieda body. Each sporocyst had two sporozoites. For the sake of small size in comparison to the others species found in the Japanese quail, Eimeria minima was proposed.
\end{abstract}

Keywords: Eimeria minima; japanese quail; Cuturnix cuturnix japonica; Brazil.

\section{Resumo}

Oocistos obtidos nas fezes de codornas (Cuturnix cuturnix japonica) quando esporulados mediam de 17,31 $\pm 1,87$ por $16,45 \pm 1,72$ $\mu \mathrm{m}$ de diâmetro com índice morfométrico de $1,05 \pm 0,04$, caracterizando-os como esféricos para subesféricos. A parede do oocistos era constituída por duas camadas distintas, a de fora era de coloração marrom, enquanto a de dentro era transparente. Alguns grânulos polares faziam-se presentes no oocisto, porém sem micrópila e resíduo. Os esporocistos eram ovóides

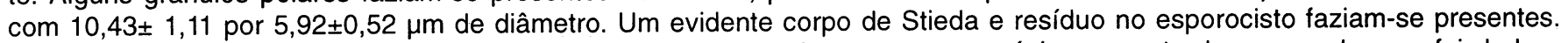
Cada esporocistos continha dois esporozoítas. Por ser uma das menores espécies encontradas em codornas, foi dada a esta espécie o nome de Eimeria minima.

Palavras-chave. Eimeria minima, codorna doméstica; Cuturnix cuturnix japonica; Brasil.

\section{Introduction}

Species of the genus Eimeria have been described in quails of the genus Cuturnix where the first citation was described by Chakravat and Kar (1947) in C. cuturnix cuturnix, common gray quail denominating it as $E$. cuturnicis. Later, Bhatia et al. (1965) when described E. bateri, confirmed this species could parasite both the common gray quail and the Japanese quail (C. c. japonica). In addition, other species were described parasiting quails as E.uzura (Tsunoda and Muraki, 1971) and $E$. tsunodai (Tsutsumi, 1972) from the Japanese quail, $E$. taldykurganica (Svanbaev and Utebaeva, 1973) from common gray quail in the Azerbaijan, and E. tahamensis (Amoudi, 1987) from quails of the Arabic peninsula (C. delegorguei arabica). Recently, the opportunity to examine grow-up Japanese quails for coccidia parasites, a new species in the genus Eimeria was reported.

\section{Material and methods}

The oocysts used in this work were obtained from feces of a group of 120 Japanese quails, which coming from a semiextensive breeding located at the Municipality of Petrópolis in the State of Rio de Janeiro, They were maintained at the W.O.Neitz experimental station for parasitological researches of the Departamento de Parasitologia Animal, Instituto de Veterinária in the Universidade Federal Rural Rio de Janeiro (www.ufrrj.br).

For the identification, the oocysts was obtained through the exam of the samples of feces, collected by the morning of the quails for 6 serial days using the centrifugal-flotation technique with saturated sugar solution. To follow the material contends the oocysts was placed in Potassium Dicromate Solution $2.5 \%$, at $27^{\circ} \mathrm{C}$ and They were submitted to aeration with aid of a fishbowl bomb. After having confirmed the sporulation of the

\footnotetext{
*Supported by CNPq.

**PIBIC (UFRRJ/CNPq) scholarship, Departamento de Parasitologia Anima (DPA), Instituto de Veterinária, Universidade Federal Rural do Rio de Janeiro (UFRRJ), BR-465 Km 07 - CEP 23890-000 Seropédica, RJ, Brazil. E-mail: teixeira @ufrrj.br

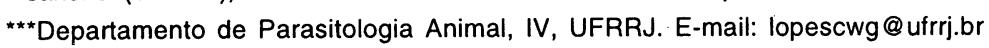


oocysts, these were concentrated through the same centrifugal-flotation technique by wash with Phosfate Buffered Solution (PBS) pH 7.0 and was centrifugated at $3000 \mathrm{rpm}$ for 10 minutes. The concentrated oocysts was suspended in PBS again, and later they were stored in Eppendorf's tubes under refrigeration at $4^{\circ} \mathrm{C}$.

The of sporulated oocysts were measured by using a triocular microscope WILD-M20 with an ocular micrometric $\mathrm{K}-15 \mathrm{X}$ in objective of 100X. Morphologic characterization was done by using a WILD drawing tube. Phothograph was taken in a triocular microscope JENAPOL/Carl Zeiss with a photographic camera model $\mathrm{f}$-KAS Automatic-2 and film Plus-X pan Kodak 125 ISSO.

\section{Results}

Description: The sporulated oocysts $(n=50)$ varied from spherical to subspherical by measuring from $17,31 \pm 1,87$ to $16,45 \pm 1,72 \mu \mathrm{m}$ in diameter with $1,05 \pm 0,04$ shape index. The wall of the oocysts was consisted by two distinct layers, being the outside layer was brownish when the inner one was hialyne. Polar granules in small number, even so the micropyle or residual body was not observed. Sporocysts were ovoids $(n=50)$, measuring from $10.43 \pm 1.11$ to $5.92 \pm 0.58 \mu \mathrm{m}$ in diameter, with a tactfull Stieda body. The sporocyst residual body was present

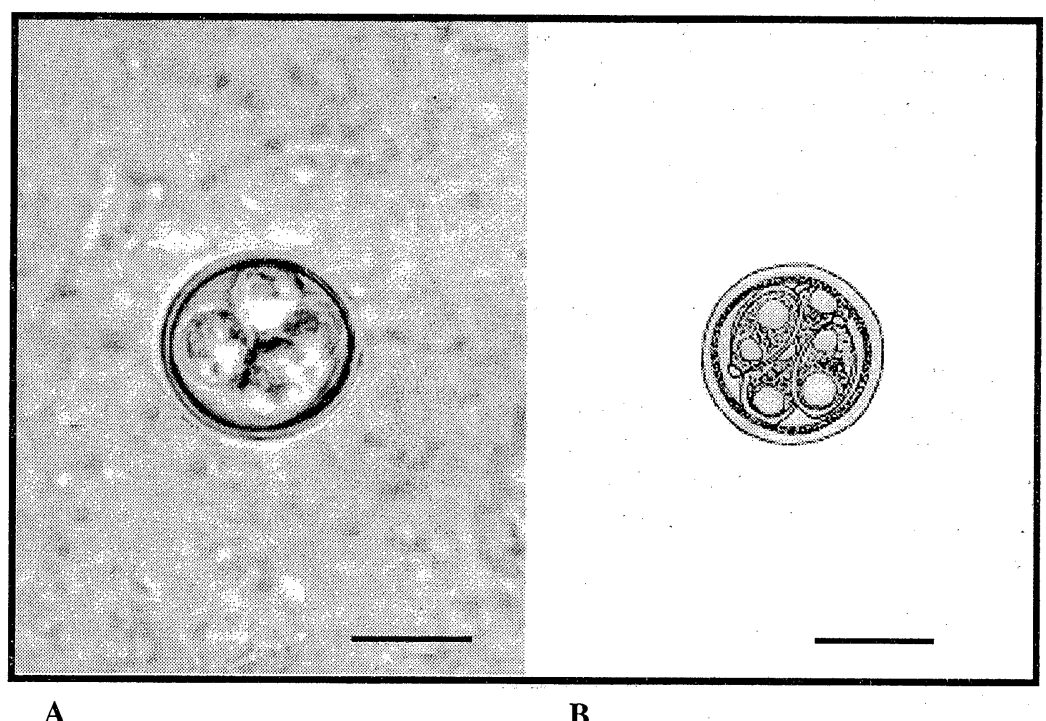

Figure 1: Eimeria minima. A- Potassium Dicromate Solution, B- drawing tube $(-=10$ with visible granules. Sporozoites into the sporocysts had a polar refractile globules of difficult visualization.

Host: C. c. japonica.

Location in the host: ignored, oocysts found in the feces.

Pre-patent period: unknow.

Sporulation: exogenous.

Locality: Municipality of Petrópolis in State of Rio de Janeiro, Brazil

Etymology: name of the species was given by being that the smallest oocyst among species found in Japanese quails.

\section{Discussion}

Several species of Eimeria were described in quails. It is important to mention that the specificity factor was not considered for quails of the genus Cuturnix, where the proximity among the host subspecies has been favorable the transmission among them, as was pointed out by Norton e Pierce (1971) when they worked with $E$. bateri in Japanese quails, although this species was previously described in the common gray quail by Bhatia et al. (1965). Like this, other factor as the morphology of the oocysts has still been continued to be of great value in the differentiation among species of the genus Eimeria (Long and Joyner, 1984). The absence of micropyle and the residual body in the oocyst were factors that allowed to separate this species from others ones already described by Chakravat and Kar, (1947), Tsunoda and Muraki, (1971), Tsutsumi, (1972), Svanbaev and Utebaeva, (1973), and Amoudi, (1987). The measurements of the oocysts was fundamental because the size was not observed until then in one of the species described in quails of the genus Cuturnix. However, Bhatia et al., (1965) found different forms of $E$. bateri, including a spherical form. This form resemble plenty the oocysts found in the present study and certainly it would be classify as similar, however, They did not evaluate the Stieda body in full detail, whose structure was pointed but discreet, expressing morphologic difference to spherical form of $E$. bateri with a prominent and piriform Stieda body. Being like this, it should be denominated as a new species different from the others described before, so it was named as Eimeria minima.

\section{Cited literature}

AMOUDI, M.A. Eimeria tahamensisn. sp. (Apicomplexa: Eimeriidae) from the Arabiam quail (Cutrunix delegorguei arabica). J. Parasitol., v. 34, p. 455-456, 1987.

BATHIA, B.B., PANDEY, T.P., PANDE, B.P. Eimeria baterin. sp. from indian common quail (Cuturnix cuturnix cuturnix). Indian $\mathrm{J}$. Microbiol., v. 5, p. 61-64, 1965.

CHAKRAVAT, M., KAR, A. B. A study on the Coccidia of Indian Birds. Proc.Roy.Soc.Edinburgh, v. 62, p. 225-223, 1947.

LONG, P.L., JOYNER, L.P. Problems in the identification of species of Eimeria. J. Protozool., v. 31, p. 535-541, 1984.
NORTON, C.C., PIERCE, M.A. The life cycle of Eimeria bateri(Protozoa: Eimeriidae) in the japanese quail Cuturnix cuturnix japonica. $J$. Protozool., v. 18, p. 57-62, 1971.

SVAMBAEV, S.K., UTEBAEVA, M.K. Coccidial infections of Phasianus cochicus mongolicus and Cutrunix cuturnix in Kazakhstan. Izev. Akad. Nauk. Kasakhskistan, SSR. S. Biology, v. 6, p. 62-68, 1973. (in Russian)

TSUNODA, L., MURAKI, Y. A new coccidium of japanese quails: Eimeria uzuran. sp. Jap. J. Vet. Sc., v. 33, p. 227-235, 1971.

TSUTSUMI, Y. Eimeria tsunodai sp. nov. (Protozoa: Eimeriidae). A caecal coccidium of japanese quails (Cuturnix cuturnix japonica). Jap. J. Vet. Sc., v. 34, p. 1-9, 1972. 